\title{
Article \\ Piezo1 Mechanosensitive Ion Channel Mediates Stretch-Induced Nppb Expression in Adult Rat Cardiac Fibroblasts
}

\author{
Meike C. Ploeg ${ }^{1}$, Chantal Munts ${ }^{1}$, Frits W. Prinzen ${ }^{1}$, Neil A. Turner ${ }^{2,3}{ }^{(D)}$, Marc van Bilsen ${ }^{1}$ \\ and Frans A. van Nieuwenhoven ${ }^{1, *(D)}$ \\ 1 Department of Physiology, Cardiovascular Research Institute Maastricht (CARIM), Maastricht University, \\ 6200 MD Maastricht, The Netherlands; m.ploeg@maastrichtuniversity.nl (M.C.P.); \\ c.munts@maastrichtuniversity.nl (C.M.); frits.prinzen@maastrichtuniversity.nl (F.W.P.); \\ marc.vanbilsen@maastrichtuniversity.nl (M.v.B.) \\ 2 Discovery and Translational Science Department, Leeds Institute of Cardiovascular and Metabolic Medicine, \\ School of Medicine, University of Leeds, Leeds LS2 9JT, UK; n.a.turner@leeds.ac.uk \\ 3 Multidisciplinary Cardiovascular Research Centre, University of Leeds, Leeds LS2 9JT, UK \\ * Correspondence: f.vannieuwenhoven@maastrichtuniversity.nl
}

check for updates

Citation: Ploeg, M.C.; Munts, C.; Prinzen, F.W.; Turner, N.A.; van Bilsen, M.; van Nieuwenhoven, F.A. Piezo1 Mechanosensitive Ion Channel Mediates Stretch-Induced Nppb Expression in Adult Rat Cardiac Fibroblasts. Cells 2021, 10, 1745. https://doi.org/10.3390/cells10071745

Academic Editors: Cord Brakebusch and Kate Møller Herum

Received: 28 May 2021

Accepted: 7 July 2021

Published: 9 July 2021

Publisher's Note: MDPI stays neutral with regard to jurisdictional claims in published maps and institutional affiliations.

Copyright: (c) 2021 by the authors. Licensee MDPI, Basel, Switzerland. This article is an open access article distributed under the terms and conditions of the Creative Commons Attribution (CC BY) license (https:/ / creativecommons.org/licenses/by/ $4.0 /)$.

\begin{abstract}
In response to stretch, cardiac tissue produces natriuretic peptides, which have been suggested to have beneficial effects in heart failure patients. In the present study, we explored the mechanism of stretch-induced brain natriuretic peptide (Nppb) expression in cardiac fibroblasts. Primary adult rat cardiac fibroblasts subjected to $4 \mathrm{~h}$ or $24 \mathrm{~h}$ of cyclic stretch $(10 \% 1 \mathrm{~Hz})$ showed a 6.6-fold or 3.2-fold $(p<0.05)$ increased mRNA expression of Nppb, as well as induction of genes related to myofibroblast differentiation. Moreover, BNP protein secretion was upregulated 5.3-fold in stretched cardiac fibroblasts. Recombinant BNP inhibited TGF $\beta 1$-induced Acta2 expression. $\mathrm{Nppb}$ expression was $>20$-fold higher in cardiomyocytes than in cardiac fibroblasts, indicating that cardiac fibroblasts were not the main source of $\mathrm{Nppb}$ in the healthy heart. Yoda1, an agonist of the Piezo1 mechanosensitive ion channel, increased Nppb expression 2.1-fold $(p<0.05)$ and significantly induced other extracellular matrix (ECM) remodeling genes. Silencing of Piezo1 reduced the stretch-induced $\mathrm{Nppb}$ and Tgfb1 expression in cardiac fibroblasts. In conclusion, our study identifies Piezo1 as mediator of stretch-induced Nppb expression, as well as other remodeling genes, in cardiac fibroblasts.
\end{abstract}

Keywords: mechanosensing; cardiac fibroblast; brain natriuretic peptide; piezo1; stretch

\section{Introduction}

Mechanical factors influence the form and function of cells [1-4]. Specifically in the heart, mechanical signals include the forces of cyclic contraction and relaxation of the myocardial walls and the hemodynamic load leading to stretch of the cardiac chambers during the filling phase, and increased wall stress during the contraction phase [5]. These factors are known to regulate myocardial function, gene expression and structural appearance [6,7].

Cardiovascular tissue is composed of cardiomyocytes, fibroblasts, vascular and immune cells which reside within the myocardial extracellular matrix (ECM) [8]. The ECM provides structure, transmits mechanical forces and modulates cell function [8,9]. Cardiac fibroblasts play an important role in the regulation of the ECM, by synthesizing structural ECM proteins (i.e., collagens), ECM degrading matrix metalloproteinases (MMPs and TIMPs) [10], growth factors such as transforming growth factor $\beta 1$ (TGF $\beta 1$ ) and matricellular proteins like tenascin C (TNC) [11] and connective tissue growth factor (CTGF) [12]. Matricellular proteins gain increasing attention for their significant role in cardiac remodeling [11]. In response to injury, cardiac fibroblasts become activated and differentiate to 
so-called myofibroblasts $[10,13]$. These myofibroblasts have special morphological and functional characteristics, such as the expression of alpha smooth muscle actin (aSMA, encoded by ACTA2 gene) $[10,14]$. TGF $\beta 1$ is known as established stimulus for myofibroblast differentiation [15,16]. Even though myofibroblast differentiation is an essential process in normal wound healing, it can result in pathological fibrosis in cases of prolonged injury or loss of regulatory mechanisms [8]. In addition to biochemical factors, mechanical cues such as mechanical strain and ECM stiffness also play an important role in regulating myofibroblast differentiation $[17,18]$. Cardiac fibroblasts express a number of different mechanosensitive ions channels that are coupled to alteration of cellular phenotype and function [19].

Cardiovascular tissues can produce natriuretic peptides in response to wall stretch [20-24]. There are three types of natriuretic peptides: atrial natriuretic peptide (ANP, encoded by NPPA gene), brain natriuretic peptide (BNP, encoded by NPPB gene), and C-type natriuretic peptide (CNP, encoded by NPPC gene) $[25,26]$. ANP and BNP are found in multiple tissues, but they are produced primarily in the cardiac atria or ventricles, respectively [27-30]. CNP is mainly produced in the endothelium [27,31]. Cyclic stretch induced increased Nppa and Nppb expression in adult rabbit cardiomyocytes [32] and human embryonic stem cell-derived cardiomyocytes (hESC-CMs) [33].

BNP inhibits collagen production and fibroblast proliferation [10], and the TGF $\beta$ activation of pro-fibrotic and inflammatory genes in cultured human cardiac fibroblasts [34]. Nppb knock out mice subjected to pressure overload by aortic constriction show increased fibrosis as well as increased mRNA levels of Tgfb3 and Col1a1 [35]. The beneficial effects of BNP in the heart has led to pharmacotherapy aimed at increasing BNP signaling in heart failure patients [36,37].

While it is generally accepted that cardiomyocytes produce BNP [32,38-42], some studies show that it is also synthesized by cardiac fibroblasts $[10,24,38,43]$. A recent paper found that stretch of human cardiac fibroblasts increased NPPB expression [43]. However, the mechanism of stretch-induced NPPB expression in cardiac fibroblasts is unknown. Blythe and colleagues very recently identified the presence of Piezo1 as a functional $\mathrm{Ca}^{2+}$ permeable mechanosensitive ion channel in both murine and human cardiac fibroblasts [44]. Therefore, we hypothesized that stretch-induced NPPB expression by cardiac fibroblasts is mediated by the mechanosensitive ion channel Piezo1.

\section{Materials and Methods}

\subsection{Isolation of Cardiac Fibroblasts and Cardiomyocytes}

Cardiac fibroblasts were isolated from cardiac ventricles (combined left and right) of adult surplus rats $(n=31)$ from any age, weight, sex or breed. Most of the rats used were either from the Lewis or Wistar strain and aged between 5 and 52 weeks. Rat cardiac ventricular fibroblasts were isolated and cultured as previously described $[9,45,46]$ in Dulbecco's modified eagles medium (DMEM; no. 22320, Gibco, Invitrogen, Breda, the Netherlands) supplemented with $10 \%(v / v)$ fetal bovine serum (FBS, Gibco), gentamicin $(50 \mu \mathrm{g} / \mathrm{mL}$, Gibco), 1\% ( $v / v)$ Insulin-Transferrin-Selenium-Sodium Pyruvate (ITS-A, Gibco) and basic fibroblast growth factor ( $1 \mathrm{ng} / \mathrm{mL}$, Gibco) ("CF culture medium"). The vast majority of these cells are fibroblast-like cells and these primary fibroblasts were used between passage 1-3. Cardiomyocytes were isolated from the left ventricle of adult male Sprague Dawley rats ( $n=6$ age 10-20 weeks) essentially as described previously [32,47]. Experiments were performed with approval of the Animal Ethical Committee of Maastricht University (DEC-2007-116, July 31, 2007) and conform to the national legislation for the protection of animals used for scientific purposes. 


\subsection{Experimental Stretch Protocols}

Cardiac fibroblasts $\left(10,000\right.$ cells $\left./ \mathrm{cm}^{2}\right)$ were plated on bioflex plates (6-well Bioflex plates, precoated with collagen-I, Flexcell Dunn Labortechnik, Asbach, Germany) in CF culture medium. The next day, $\mathrm{CF}$ culture medium was replaced by DMEM supplemented with gentamicin $(50 \mu \mathrm{g} / \mathrm{mL}$, Gibco). After $24 \mathrm{~h}$, cardiac fibroblasts were subjected to $10 \%$ cyclic $(1 \mathrm{~Hz})$ equibiaxial stretch, (Flexcell FX-4000 strain unit, Dunn Labortechnik) for $4 \mathrm{~h}$, $6 \mathrm{~h}$ or $24 \mathrm{~h}$. Control, non-stretched cells were subjected to identical conditions however, without stretch being applied.

\subsection{Experimental Stimuli}

To determine regulation and effects of BNP, cardiac fibroblasts $\left(10,000\right.$ cells $\left./ \mathrm{cm}^{2}\right)$ were serum-starved for $24 \mathrm{~h}$ before incubation with TGF $\beta 1(1 \mathrm{ng} / \mathrm{mL}$, R\&D systems, Minneapolis, MN, USA), Yoda1 (10 $\mu \mathrm{M}$, Tocris, Bristol, UK) and BNP (1 $\mu \mathrm{M}, \mathrm{R} \& \mathrm{D}$ systems) for $4 \mathrm{~h}$ or $24 \mathrm{~h}$.

\subsection{Gene Expression Analysis}

Total RNA was isolated from cells using an RNA isolation kit (Omega Biotek, Norcross, GA, USA) and reversed transcribed into cDNA using the iScript cDNA synthesis kit (Biorad, Hercules, CA, USA) according to the manufacturer's instructions. Real-time PCR was performed on an iCycler accompanied by the My IQ single color real-time PCR detection system using iQ SYBR-Green Supermix (Biorad) [9]. Gene expression levels of Alpha-smooth muscle actin (Acta2), Connective tissue growth factor (Ctgf), Transforming growth factor beta 1 (Tgfb1), Tenascin C (Tnc), Piezo1, Atrial Natriuretic peptide (Nppa), $\mathrm{C}$-Type natriuretic peptide (Nppc) and Brain Natriuretic Peptide (Nppb) were normalized using the housekeeping gene Cyclophilin-A (Cyclo), and their relative expression was calculated using the comparative threshold cycle $(\mathrm{Ct})$ method by calculating $2^{\Delta \mathrm{Ct}}$ (e.g., $2^{(\text {Cyclophilin } \mathrm{Ct}-\mathrm{BNP} \mathrm{Ct})}$ ). The gene expression values were multiplied by 1000 (formula $\left.1000 * 2^{\Delta \mathrm{Ct}}\right)$, to enhance readability. The sequences of the specific primers used are provided below (Table 1).

Table 1. Gene-specific primer sequences used for quantitative real-time PCR.

\begin{tabular}{lll}
\hline Gene & Forward Primer & Reverse Primer \\
\hline Alpha-smooth muscle actin (Acta2) & AAGGCCAACCGGGAGAAAAT & AGTCCAGCACAATACCAGTTGT \\
Connective tissue growth factor (Ctgf) & CACAGAGTGGAGCGCCTGTTC & GATGCACTTTTTGCCCTTCTTAATG \\
Transforming growth factor, beta 1 (Tgfb1) & GCACCATCCATGACATGAAC & GCTGAAGCAGTAGTTGGTATC \\
Tenascin C (Tnc) & TCTGTCCTGGACTGCTGATG & TGGCCTCTCTGAGACCTGTT \\
Piezo1 & TTGCGTACGTTCACGAAGGA & TTCGCTCACGTAAAGCTGGT \\
Atrial Natriuretic peptide (Nppa) & ATCACCAAGGGCTTCTTCCT & TGTTGGACACCGCACTGTAT \\
Brain Natriuretic Peptide (Nppb) & AGACAGCTCTCAAAGGACCA & CTATCTTCTGCCCAAAGCAG \\
C-Type natriuretic peptide (Nppc) & ACAAAGGCGGCAACAAGAAG & GCAGTTCCCAATCCGCCG \\
Cyclophilin-A (Cyclo) & CAAATGCTGGACCAAACACAA & TTCACCTTCCCAAAGACCACAT \\
\hline
\end{tabular}

\subsection{BNP ELISA}

Conditioned media were collected after the $24 \mathrm{~h}$ stretch-experiments and stored at $-80^{\circ} \mathrm{C}$ for subsequent analysis. The conditioned media were concentrated (approximately 10-fold) using Amicon Ultra 3k devices (Merck-Millipore, Burlington, MA, USA) and the concentration of BNP was determined by ELISA (ab108815, Abcam, Cambridge, UK) according to the manufacturer's instructions.

\subsection{Gene Silencing}

Cardiac fibroblasts $\left(10,000\right.$ cells $\left./ \mathrm{cm}^{2}\right)$ were plated on bioflex plates (6-well Bioflex plates, precoated with collagen-I, Flexcell Dunn Labortechnik) in CF culture medium and transfected with $10 \mathrm{nM}$ Piezo1-specific Silencer Select Pre-Designed siRNA (4390771, siRNA s107968, Life Technologies, Carlsbad, CA, USA) or Silencer Select Negative Control 
No. 1 siRNA (4390843, Life Technologies) using Lipofectamine RNAiMAX reagent (Life Technologies) in Opti-MEM (Gibco) according to the manufacturer's instructions. After $72 \mathrm{~h}$ cells were exposed to the stretch protocol described above.

\subsection{Statistics}

Data are presented as mean or individual data points and were analyzed with Wilcoxon matched pairs test or Friedman test, with Dunn posthoc test where appropriate. Differences were considered statistically significant when $p<0.05$.

\section{Results}

\subsection{Mechanical Stretch Induces BNP Expression in Cardiac Fibroblasts}

Cardiac fibroblasts exposed to cyclic stretch $(10 \%, 1 \mathrm{~Hz})$ for $4 \mathrm{~h}$ showed a significant increase in mRNA expression of Tgfb1, Tnc, Ctgf and Acta2 compared to non-stretched controls (Figure 1a). After $24 \mathrm{~h}$ of cyclic stretch the effect remained for Tgfb1, Ctgf and Acta2 (Figure 1b). Interestingly, Nppb mRNA expression was significantly upregulated by 6.6-fold after $4 \mathrm{~h}$ stretch (Figure 1a) and 3.2-fold after $24 \mathrm{~h}$ stretch (Figure 1b) compared to non-stretched controls. BNP-protein secretion was upregulated by 5.3-fold in stretched cells compared to non-stretched cells, measured from conditioned media after $24 \mathrm{~h}$ stretch (Figure 1c). mRNA expression of Nppa and Nppc were below the detection limit. Cyclic stretch did not influence the mRNA expression of the mechanosenstive ion channel Piezo1 after $4 \mathrm{~h}$ (Figure 1a) or $24 \mathrm{~h}$ (Figure 1b)

(a) Gene expression changes after $4 \mathrm{~h}$ stretch
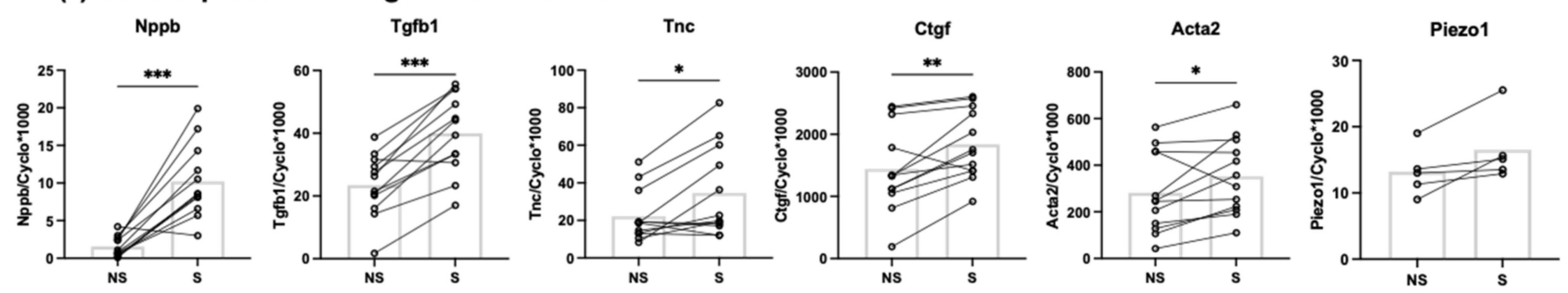

(b) Gene expression changes after $24 \mathrm{~h}$ stretch

Nppb

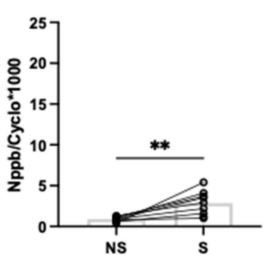

Tgfb1

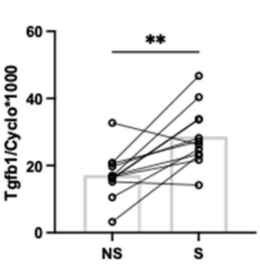

Tnc

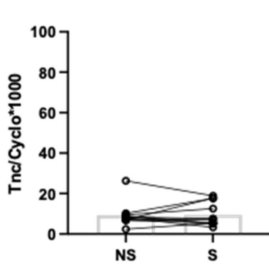

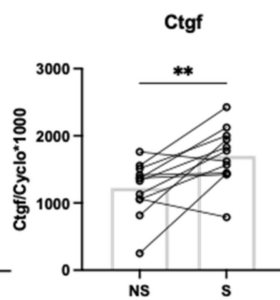

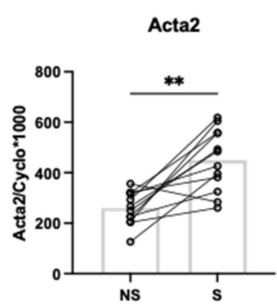

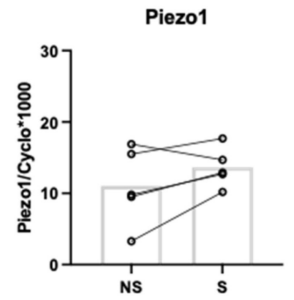

(c) BNP Protein secretion in conditioned media after $24 \mathrm{~h}$ stretch BNP

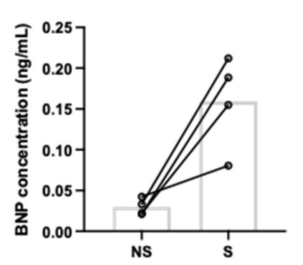

Figure 1. Relative mRNA expression levels of Nppb, Tgfb1, Tnc, Ctgf, Acta2, and Piezo1 in cardiac fibroblasts exposed to $10 \% 1 \mathrm{~Hz}$ cyclic stretch (S) or non-stretched (NS) conditions for $4 \mathrm{~h}(n=5-12)$ (a) or $24 \mathrm{~h}(n=5-12)(\mathbf{b})$. BNP-protein concentration in conditioned media from stretched and non-stretched cardiac fibroblasts $(n=4)(\mathrm{c}) .{ }^{*} p<0.05 ;{ }^{* *} p<0.01$; *** $p<0.001$. Bar indicates mean. 


\subsection{Recombinant BNP Inhibits Profibrotic Gene Expression in Cardiac Fibroblasts}

To confirm the anti-fibrotic effect of BNP [34], cardiac fibroblasts were stimulated with recombinant BNP with or without TGF $\beta 1$ for $4 \mathrm{~h}$ or $24 \mathrm{~h}$. The expression of Acta2 and Ctgf in cardiac fibroblasts was investigated by RT-qPCR. Acta2 showed a significant reduction in expression after the addition of BNP, with and without TGF $\beta 1$ after $4 \mathrm{~h}$ (Figure 2a). This effect was not maintained after $24 \mathrm{~h}$ (Figure 2b). A similar trend was observed for Ctgf, but this failed to reach statistical significance.

(a) Gene expression changes after $4 \mathrm{~h}$ incubation

Acta2

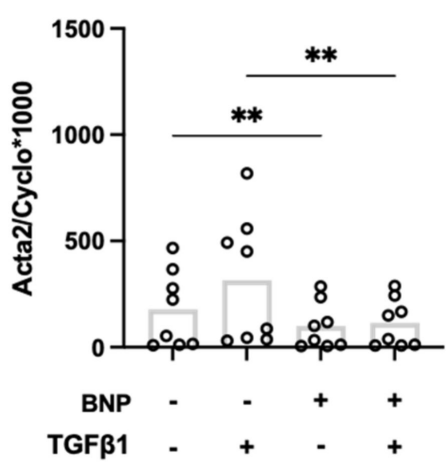

Ctgf

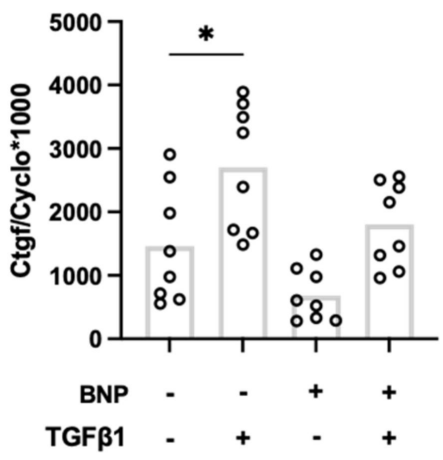

(b) Gene expression changes after $24 \mathrm{~h}$ incubation

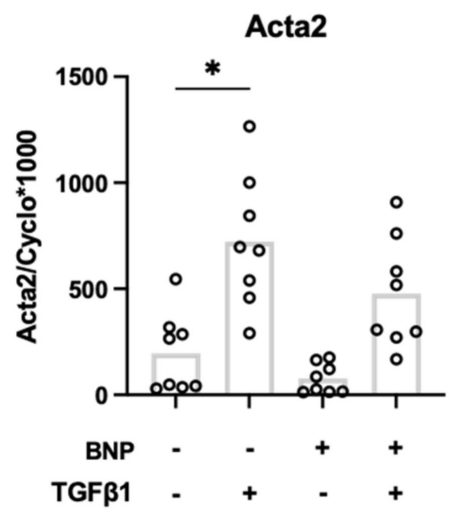

Ctgf

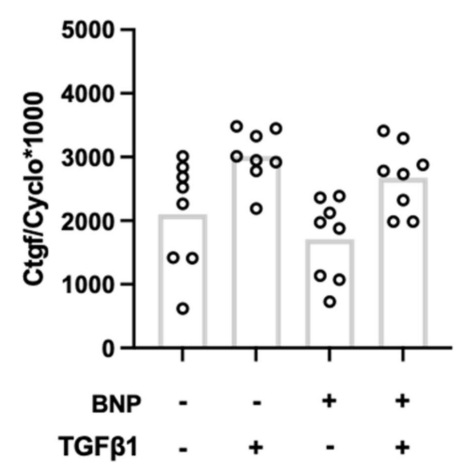

Figure 2. Relative mRNA expression levels of Ctgf and Acta2 in cardiac fibroblasts exposed to recombinant $\mathrm{BNP}$ and/or TGF $\beta 1$ after $4 \mathrm{~h}(\mathbf{a})$ and $24 \mathrm{~h}(\mathbf{b})(n=8){ }^{*} p<0.05 ;{ }^{* *} p<0.01$. Bar indicates mean.

\subsection{Both Cardiomyocytes and Cardiac Fibroblasts Express Nppb}

To investigate the relative mRNA expression of Nppb by cardiac fibroblasts compared to cardiomyocytes, we performed RT-qPCR on adult rat cardiomyocytes and cardiac fibroblasts. Cardiac fibroblasts showed 300-fold lower expression of Myh7 (myocyte marker) (Figure 3b) and 500-fold higher expression of Colla1 compared to cardiomyocytes (Figure 3c). The Nppb expression in cardiomyocytes was 20-fold higher compared to cardiac fibroblasts, indicating that fibroblasts are not the main source of myocardial Nppb expression, at least under basal conditions (Figure 3a). 
(a)

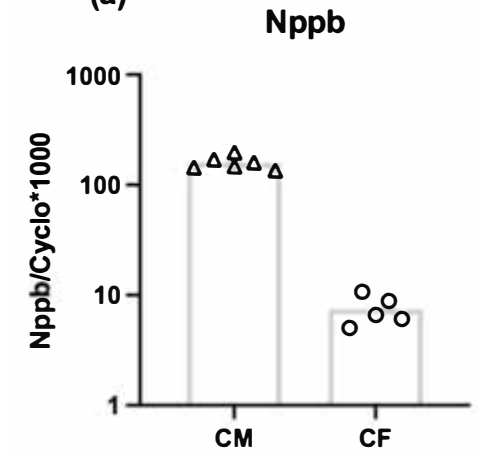

(b)

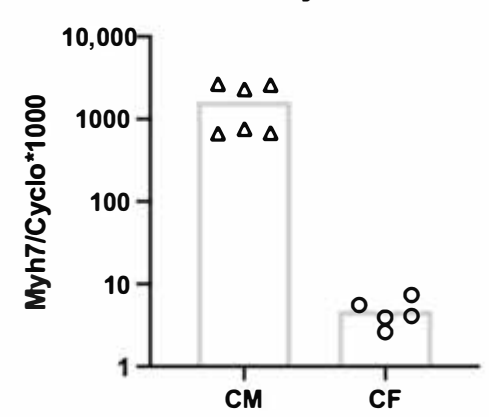

(c)

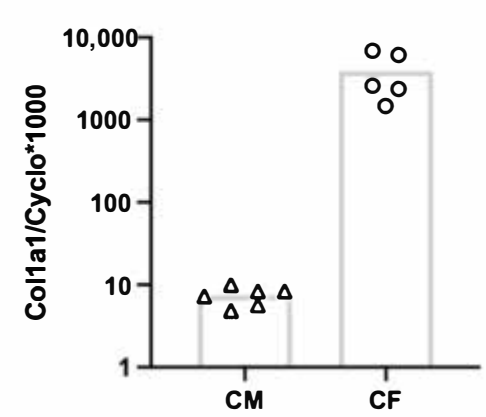

Figure 3. Relative mRNA expression levels of Nppb (a) Myh7 (b) and Col1a1 (c) in cardiomyocytes (CM) $(n=6)$ and cardiac fibroblasts (CF) $(n=5)$ (presented on a logarithmic scale). Bar indicates mean.

\subsection{Stretch-Induced Nppb and Tgfb1 Expression Are Mediated by Piezo1}

To gain insight into the functional role of Piezo1 activation in cardiac fibroblasts, we first investigated the effect of the Piezo1 agonist Yoda1. Treatment of unstretched fibroblasts with $10 \mu \mathrm{M}$ Yoda1 for $4 \mathrm{~h}$ significantly increased mRNA expression of Tgfb1, Tnc and Nppb (Figure 4a). Yoda1 stimulation also gave a significant increased expression of Piezo1 mRNA.

(a) Gene expression changes after $4 \mathrm{~h}$ Yoda1 treatment
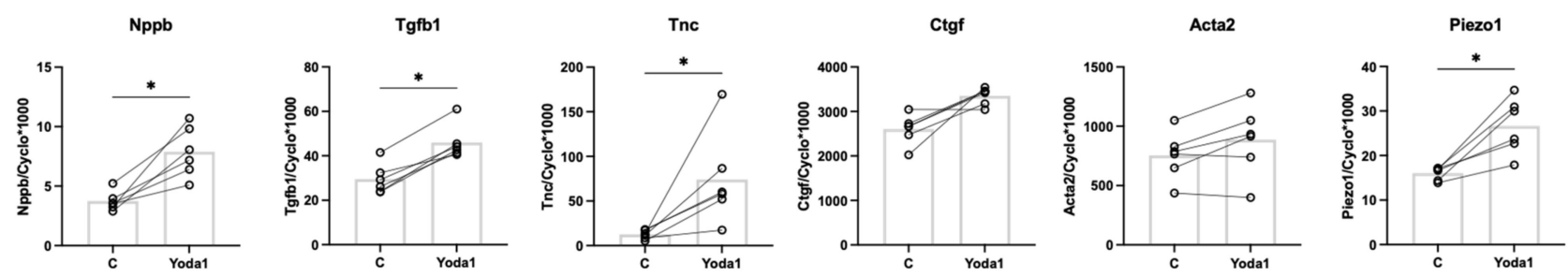

(b) Gene expression changes after $6 \mathrm{~h}$ stretch in combination with Piezo1 silencing
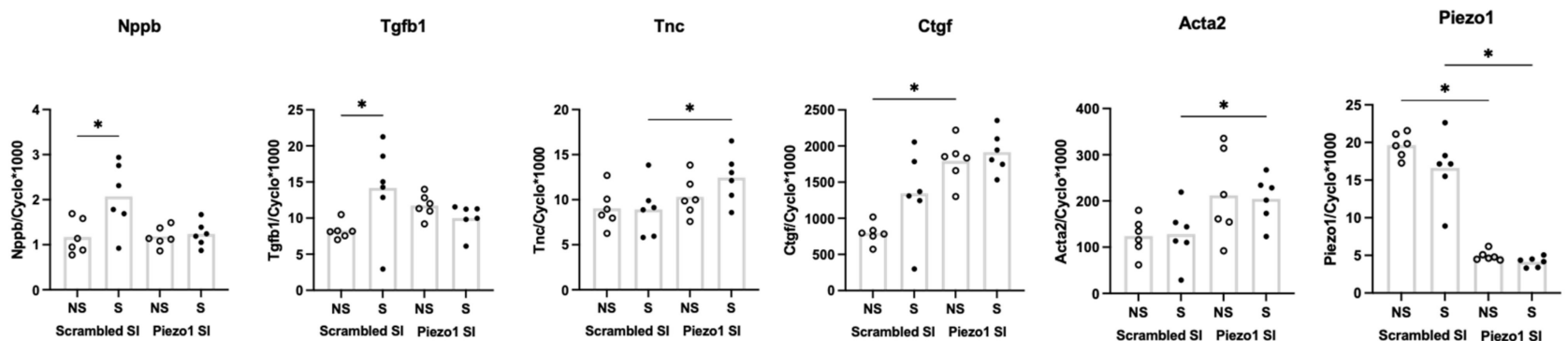

Figure 4. Relative mRNA expression levels of Nppb, Tgfb1, Tnc, Ctgf, Acta2, and Piezo1 in cardiac fibroblasts after stimulation with Piezo1 agonist Yoda1 after $4 \mathrm{~h}(n=6)$ (a) Relative mRNA expression of Nppb, Tgfb1, Tnc, Ctgf, Acta2, and Piezo1 in cardiac fibroblasts exposed to $10 \% 1 \mathrm{~Hz}$ cyclic stretch for $6 \mathrm{~h}(\mathrm{~S})$ or non-stretched (NS) conditions after transfection with either control siRNA (Scrambled SI) or Piezo1-specific siRNA (Piezo1 SI) $(n=6)(\mathbf{b}) * p<0.05$. Bar indicates mean.

Next, the effect of siRNA-mediated Piezo1 silencing was explored. Piezo1 silencing was successful in reducing the expression of Piezo1 by approximately $80 \%$ (Figure $4 \mathrm{~b}$ ). Piezo1 silencing increased the expression of Ctgf under non-stretched conditions, and the Tnc and Acta2 expression levels under stretch. The stretch-induced increase in Tgfb1 expression was absent following Piezo1-silencing (Figure 4b). Piezo1 silencing also prevented stretch-induced $\mathrm{Nppb}$ expression, supporting the hypothesis that stretched induced Nppb expression is Piezo1 mediated. 


\section{Discussion}

The present study identifies Piezo1 as the mechanosensitive ion channel responsible for the stretch-induced Nppb and Tgfb1 expression in cardiac fibroblasts. Our study also confirms the finding of Watson and colleagues of stretch-induced Nppb upregulation in human ventricular cardiac fibroblasts [43] and the anti-fibrotic effect of BNP [10,34].

Natriuretic peptides are thought to be part of a potentially beneficial counter-regulatory system in heart failure [48]. BNP might prevent the development of cardiac fibrosis by serving as a cardiomyocyte-derived antifibrotic signal to cardiac fibroblasts during the process of cardiac remodeling [35]. However, others have shown Nppb expression by fibroblasts $[10,38,49]$. We confirmed the expression of Nppb in cardiac fibroblasts, on mRNA as well as protein level in response to cyclic stretch. Although expression levels of $\mathrm{Nppb}$ in our isolated cardiac fibroblasts were lower than found in isolated cardiomyocytes, it is important to note that the cells were derived from healthy animals. Furthermore, the locally produced BNP by cardiac fibroblasts might still have important autocrine or paracrine functions. Cyclic stretch also upregulated the mRNA expression of Tgfb1, Tnc, Ctgf and Acta2 after $4 \mathrm{~h}$, which was maintained for all but Tnc after $24 \mathrm{~h}$. Together, these genes are all related to myofibroblast differentiation and cardiac remodeling [10-12,14-16]. Their upregulation gives some implications on the process of myofibroblast differentiation being started or already ongoing. Cyclic stretch did not affect the mRNA expression of Piezo1, after $4 \mathrm{~h}$ or $24 \mathrm{~h}$.

The antifibrotic effect of BNP has been shown previously [34], which we confirmed specifically for myofibroblast differentiation related gene Acta2. Therefore, it is possible that BNP produced by fibroblasts acts as a local autocrine/paracrine factor modulating cardiac fibroblast activation and tissue remodeling within the heart [50]. Differences between $4 \mathrm{~h}$ and $24 \mathrm{~h}$ incubation with BNP and/or TGF $\beta 1$ in our cell culture experiments might be due to the relative short half-life of both BNP and TGF $\beta 1$. Therefore, both products are degraded within hours and their effects might be stronger at $4 \mathrm{~h}$ as compared to $24 \mathrm{~h}$.

The well-known Piezo1 agonist Yoda1 increased the mRNA expression on Nppb, Tgfb, Tnc and Piezo1. For Nppb, Tgfb1 and Tnc this is in accordance with the results of $4 \mathrm{~h}$ and $24 \mathrm{~h}$ of cyclic stretch, activating the Piezo1 mechanosensitive ion channel. The effect of Yoda1 on Piezo1 expression levels is unexpected as previous experiments showed no effect of $24 \mathrm{~h}$ Yoda1 stimulation on Piezo1 expression levels in murine cardiac fibroblasts [44]. The induction of Piezo1 expression by its agonist Yoda1 implies a positive feedback loop, which merits further investigation. In contrast to Yoda1, cyclic stretch did not affect Piezo1 mRNA expression. A possible explanation for the difference between the cyclic stretch and Yoda1, might be that Yoda1 is a stronger stimulus than stretch. On the other hand, stretch significantly increased the mRNA expression of Acta 2 and Ctgf after $4 \mathrm{~h}$, but Yoda1 does not. This might be due to the low numbers of cardiac fibroblast isolations $(n=6)$ used in the Yoda1 experiment; Although no statistically significant difference was found, Yoda1 increased both Ctgf $(p=0.06)$ and Acta2 $(p=0.1)$ mRNA levels, which fits with the results from the stretch experiments.

Silencing Piezo1 increased the mRNA expression levels of Ctgf in non-stretched cells and of Tnc and Acta2 in stretched cells. It is possible that the Piezo1 channel is active under control conditions, and inhibits the expression of these genes. However, this would contradict our observation that Yoda1 (which activates Piezo1) stimulated Tnc expression. Possibly, silencing of Piezo1 led to cellular compensatory mechanisms that indirectly affected the expression of these genes. Obviously, the mechanisms by which Piezo1-silencing affected Ctgf, Tnc and Acta2 mRNA expression levels are not clear and further studies are warranted to investigate this. Previously, our colleagues from the Leeds group showed that IL-6 expression and secretion in cardiac fibroblasts was inhibited by Piezo1 silencing, indicating a role for Piezo1 signaling in the expression of this pro-inflammatory gene [44]. Interestingly, this was depending on substrate stiffness and/or composition as the effect was absent when cells were cultured on regular noncoated cell culture plates (rigid plastic) $[18,44]$. Stiffness of standard plastic culture plates 
are estimated in the gigapascal (GPa) range [51]. The Bioflex plates we have used for the stretch experiment have a stiffness 1000 times less $(\sim 1$ megapascal, $\mathrm{MPa})$ than those standard culture plates. However, the stiffness of healthy myocardial tissue is estimated to be 10 kilopascal (kPa) [51-53], making myocardial tissue stiffness 100 times less than the Bioflex plates. Therefore, even though the Bioflex plates are softer than regular culture plates, they are still stiff compared to healthy myocardial tissue. Of note, the stiffness of fibrotic myocardium is estimated at $20-100 \mathrm{kPa}$ [51-53]. It has also been shown previously that Piezo1 reacts to stiffness, in both stem cells [54] and atrial fibroblasts [55].

In the present study, we did not investigate the mechanism of Piezo1-induced effects on gene expression. However, the Leeds group has reported on how Il-6 expression is linked to Piezo1 [44]. They suggest an important role for the p38 MAPK pathway in Piezo1induced Il-6 gene expression, in which p38 activation was depending on extracellular $\mathrm{Ca}^{2+}$. A similar activation pathway might be the case for Nppb or Tgfb1, but the mechanism of Piezo1 activation on Nppb or Tgfb1 expression requires further research.

In conclusion, the present study shows that both stretch-induced Nppb and Tgfb1 expression in adult rat cardiac fibroblasts is mediated by the mechanosensitive ion channel Piezo1. Furthermore, BNP protein levels were upregulated in stretched cardiac fibroblasts and recombinant BNP inhibited TGF $\beta 1$-induced Acta2 expression in cardiac fibroblasts. Together, these results indicate that Piezo1 is an important mechanosensitive ion channel mediating stretch-induced activation of cardiac fibroblasts.

Author Contributions: Conceptualization, M.C.P., M.v.B., F.A.v.N.; performed experiments and produced data M.C.P., C.M.; data analyses, M.C.P., C.M., F.A.v.N.; writing-original draft preparation, M.C.P., F.A.v.N.; writing-review and editing, M.C.P., C.M., F.W.P., N.A.T., M.v.B., F.A.v.N. All authors have read and agreed to the published version of the manuscript.

Funding: This research received no external funding.

Institutional Review Board Statement: Not applicable.

Informed Consent Statement: Not applicable.

Data Availability Statement: The data presented in this study are available from the corresponding author upon request.

Conflicts of Interest: The authors declare no conflict of interest.

\section{References}

1. Hoffman, B.D.; Grashoff, C.; Schwartz, M.A. Dynamic molecular processes mediate cellular mechanotransduction. Nature 2011, 475, 316-323. [CrossRef] [PubMed]

2. Orr, A.W.; Helmke, B.P.; Blackman, B.R.; Schwartz, M.A. Mechanisms of mechanotransduction. Dev. Cell 2006, 10, 11-20. [CrossRef]

3. Chen, C.S. Mechanotransduction-a field pulling together? J. Cell Sci 2008, 121, 3285-3292. [CrossRef] [PubMed]

4. Geiger, B.; Spatz, J.P.; Bershadsky, A.D. Environmental sensing through focal adhesions. Nat. Rev. Mol. Cell Biol 2009, 10, 21-33. [CrossRef] [PubMed]

5. Zimmermann, W.H. Biomechanical regulation of in vitro cardiogenesis for tissue-engineered heart repair. Stem Cell Res. 2013, 4, 137. [CrossRef] [PubMed]

6. Grossman, W.; Jones, D.; McLaurin, L.P. Wall stress and patterns of hypertrophy in the human left ventricle. J. Clin. Investig. 1975, 56, 56-64. [CrossRef]

7. Toischer, K.; Rokita, A.G.; Unsold, B.; Zhu, W.; Kararigas, G.; Sossalla, S.; Reuter, S.P.; Becker, A.; Teucher, N.; Seidler, T.; et al. Differential cardiac remodeling in preload versus afterload. Circulation 2010, 122, 993-1003. [CrossRef]

8. Frangogiannis, N.G. The extracellular matrix in myocardial injury, repair, and remodeling. J. Clin. Invest. 2017, 127, 1600-1612. [CrossRef]

9. Van Nieuwenhoven, F.A.; Munts, C.; Op ‘t Veld, R.C.; Gonzalez, A.; Diez, J.; Heymans, S.; Schroen, B.; van Bilsen, M. Cartilage intermediate layer protein 1 (CILP1): A novel mediator of cardiac extracellular matrix remodelling. Sci Rep. 2017, 7, 16042. [CrossRef]

10. Tsuruda, T.; Boerrigter, G.; Huntley, B.K.; Noser, J.A.; Cataliotti, A.; Costello-Boerrigter, L.C.; Chen, H.H.; Burnett, J.C., Jr. Brain natriuretic Peptide is produced in cardiac fibroblasts and induces matrix metalloproteinases. Circ. Res. 2002, 91, 1127-1134. [CrossRef] [PubMed] 
11. Imanaka-Yoshida, K. Tenascin-C in cardiovascular tissue remodeling: From development to inflammation and repair. Circ. J. 2012, 76, 2513-2520. [CrossRef]

12. Daniels, A.; van Bilsen, M.; Goldschmeding, R.; van der Vusse, G.J.; van Nieuwenhoven, F.A. Connective tissue growth factor and cardiac fibrosis. Acta Physiol (Oxf) 2009, 195, 321-338. [CrossRef]

13. Powell, D.W.; Mifflin, R.C.; Valentich, J.D.; Crowe, S.E.; Saada, J.I.; West, A.B. Myofibroblasts. I. Paracrine cells important in health and disease. Am. J. Physiol 1999, 277, C1-C9. [CrossRef] [PubMed]

14. van den Borne, S.W.; Diez, J.; Blankesteijn, W.M.; Verjans, J.; Hofstra, L.; Narula, J. Myocardial remodeling after infarction: The role of myofibroblasts. Nat. Rev. Cardiol 2010, 7, 30-37. [CrossRef] [PubMed]

15. Tarbit, E.; Singh, I.; Peart, J.N.; Rose'Meyer, R.B. Biomarkers for the identification of cardiac fibroblast and myofibroblast cells. Heart Fail. Rev. 2019, 24, 1-15. [CrossRef]

16. Swaney, J.S.; Roth, D.M.; Olson, E.R.; Naugle, J.E.; Meszaros, J.G.; Insel, P.A. Inhibition of cardiac myofibroblast formation and collagen synthesis by activation and overexpression of adenylyl cyclase. Proc. Natl Acad Sci U S A 2005, 102, 437-442. [CrossRef] [PubMed]

17. Hinz, B. The myofibroblast: Paradigm for a mechanically active cell. J. Biomech 2010, 43, 146-155. [CrossRef]

18. Yong, K.W.; Li, Y.; Huang, G.; Lu, T.J.; Safwani, W.K.; Pingguan-Murphy, B.; Xu, F. Mechanoregulation of cardiac myofibroblast differentiation: Implications for cardiac fibrosis and therapy. Am. J. Physiol Heart Circ. Physiol 2015, 309, H532-H542. [CrossRef]

19. Stewart, L.; Turner, N.A. Channelling the Force to Reprogram the Matrix: Mechanosensitive Ion Channels in Cardiac Fibroblasts Cells 2021, 10, 990. [CrossRef]

20. Kinnunen, P.; Vuolteenaho, O.; Ruskoaho, H. Mechanisms of Atrial and Brain Natriuretic Peptide Release From Rat Ventricular Myocardium: Effect of Stretching. Endocrinology 1993, 132, 1961-1970. [CrossRef] [PubMed]

21. Toth, M.; Vuorinen, K.H.; Vuolteenaho, O.; Hassinen, I.E.; Uusimaa, P.A.; Leppaluoto, J.; Ruskoaho, H. Hypoxia stimulates release of ANP and BNP from perfused rat ventricular myocardium. Am. J. Physiol 1994, 266, H1572-H1580. [CrossRef] [PubMed]

22. Zois, N.E.; Bartels, E.D.; Hunter, I.; Kousholt, B.S.; Olsen, L.H.; Goetze, J.P. Natriuretic peptides in cardiometabolic regulation and disease. Nat. Rev. Cardiol 2014, 11, 403-412. [CrossRef] [PubMed]

23. Fu, S.; Ping, P.; Wang, F.; Luo, L. Synthesis, secretion, function, metabolism and application of natriuretic peptides in heart failure J. Biol Eng 2018, 12, 2. [CrossRef] [PubMed]

24. Jarai, R.; Kaun, C.; Weiss, T.W.; Speidl, W.S.; Rychli, K.; Maurer, G.; Huber, K.; Wojta, J. Human cardiac fibroblasts express B-type natriuretic peptide: Fluvastatin ameliorates its up-regulation by interleukin-1alpha, tumour necrosis factor-alpha and transforming growth factor-beta. J. Cell Mol. Med. 2009, 13, 4415-4421. [CrossRef] [PubMed]

25. Del Ry, S.; Cabiati, M.; Lionetti, V.; Emdin, M.; Recchia, F.A.; Giannessi, D. Expression of C-type natriuretic peptide and of its receptor NPR-B in normal and failing heart. Peptides 2008, 29, 2208-2215. [CrossRef] [PubMed]

26. Maisel, A.S.; Duran, J.M.; Wettersten, N. Natriuretic Peptides in Heart Failure: Atrial and B-type Natriuretic Peptides. Heart Fail. Clin. 2018, 14, 13-25. [CrossRef] [PubMed]

27. Forte, M.; Madonna, M.; Schiavon, S.; Valenti, V.; Versaci, F.; Zoccai, G.B.; Frati, G.; Sciarretta, S. Cardiovascular Pleiotropic Effects of Natriuretic Peptides. Int J. Mol. Sci 2019, 20, 3874. [CrossRef]

28. He, X.L.; Dukkipati, A.; Garcia, K.C. Structural determinants of natriuretic peptide receptor specificity and degeneracy. J. Mol. Biol 2006, 361, 698-714. [CrossRef]

29. Matsuo, A.; Nagai-Okatani, C.; Nishigori, M.; Kangawa, K.; Minamino, N. Natriuretic peptides in human heart: Novel insight into their molecular forms, functions, and diagnostic use. Peptides 2019, 111, 3-17. [CrossRef] [PubMed]

30. Potter, L.R.; Yoder, A.R.; Flora, D.R.; Antos, L.K.; Dickey, D.M. Natriuretic peptides: Their structures, receptors, physiologic functions and therapeutic applications. Handb Exp. Pharm. 2009, 341-366. [CrossRef]

31. Moyes, A.J.; Chu, S.M.; Aubdool, A.A.; Dukinfield, M.S.; Margulies, K.B.; Bedi, K.C.; Hodivala-Dilke, K.; Baliga, R.S.; Hobbs, A.J. C-type natriuretic peptide co-ordinates cardiac structure and function. Eur Heart J. 2020, 41, 1006-1020. [CrossRef] [PubMed]

32. Blaauw, E.; van Nieuwenhoven, F.A.; Willemsen, P.; Delhaas, T.; Prinzen, F.W.; Snoeckx, L.H.; van Bilsen, M.; van der Vusse, G.J. Stretch-induced hypertrophy of isolated adult rabbit cardiomyocytes. Am. J. Physiol Heart Circ. Physiol 2010, 299, H780-H787. [CrossRef]

33. Ovchinnikova, E.; Hoes, M.; Ustyantsev, K.; Bomer, N.; de Jong, T.V.; van der Mei, H.; Berezikov, E.; van der Meer, P. Modeling Human Cardiac Hypertrophy in Stem Cell-Derived Cardiomyocytes. Stem Cell Rep. 2018, 10, 794-807. [CrossRef]

34. Kapoun, A.M.; Liang, F.; O'Young, G.; Damm, D.L.; Quon, D.; White, R.T.; Munson, K.; Lam, A.; Schreiner, G.F.; Protter, A.A. B-type natriuretic peptide exerts broad functional opposition to transforming growth factor-beta in primary human cardiac fibroblasts: Fibrosis, myofibroblast conversion, proliferation, and inflammation. Circ. Res. 2004, 94, 453-461. [CrossRef] [PubMed]

35. Tamura, N.; Ogawa, Y.; Chusho, H.; Nakamura, K.; Nakao, K.; Suda, M.; Kasahara, M.; Hashimoto, R.; Katsuura, G.; Mukoyama, M.; et al. Cardiac fibrosis in mice lacking brain natriuretic peptide. Proc. Natl Acad Sci U S A 2000, 97, 4239-4244. [CrossRef]

36. Ichiki, T.; Dzhoyashvili, N.; Burnett, J.C., Jr. Natriuretic peptide based therapeutics for heart failure: Cenderitide: A novel first-in-class designer natriuretic peptide. Int J. Cardiol 2019, 281, 166-171. [CrossRef]

37. Jhund, P.S.; McMurray, J.J. The neprilysin pathway in heart failure: A review and guide on the use of sacubitril/valsartan. Heart 2016, 102, 1342-1347. [CrossRef] [PubMed] 
38. Makino, N.; Sugano, M.; Satoh, S.; Oyama, J.; Maeda, T. Peroxisome Proliferator-Activated Receptor- $\gamma$ Ligands Attenuate Brain Natriuretic Peptide Production and Affect Remodeling in Cardiac Fibroblasts in Reoxygenation After Hypoxia. Cell Biochem. Biophys. 2006, 44, 065-072. [CrossRef]

39. Morita, E.; Yasue, H.; Yoshimura, M.; Ogawa, H.; Jougasaki, M.; Matsumura, T.; Mukoyama, M.; Nakao, K. Increased plasma levels of brain natriuretic peptide in patients with acute myocardial infarction. Circulation 1993, 88, 82-91. [CrossRef] [PubMed]

40. Nishikimi, T.; Yoshihara, F.; Morimoto, A.; Ishikawa, K.; Ishimitsu, T.; Saito, Y.; Kangawa, K.; Matsuo, H.; Omae, T.; Matsuoka, H. Relationship Between Left Ventricular Geometry and Natriuretic Peptide Levels in Essential Hypertension. Hypertension 1996, 28, 22-30. [CrossRef]

41. Koglin, J.; Pehlivanli, S.; Schwaiblmair, M.; Vogeser, M.; Cremer, P.; vonScheidt, W. Role of brain natriuretic peptide in risk stratification of patients with congestive heart failure. J. Am. Coll. Cardiol. 2001, 38, 1934-1941. [CrossRef]

42. Nishikimi, T.; Maeda, N.; Matsuoka, H. The role of natriuretic peptides in cardioprotection. Cardiovasc Res. 2006, 69, 318-328. [CrossRef]

43. Watson, C.J.; Phelan, D.; Xu, M.; Collier, P.; Neary, R.; Smolenski, A.; Ledwidge, M.; McDonald, K.; Baugh, J. Mechanical stretch up-regulates the B-type natriuretic peptide system in human cardiac fibroblasts: A possible defense against transforming growth factor-beta mediated fibrosis. Fibrogenesis Tissue Repair 2012, 5, 9. [CrossRef] [PubMed]

44. Blythe, N.M.; Muraki, K.; Ludlow, M.J.; Stylianidis, V.; Gilbert, H.T.J.; Evans, E.L.; Cuthbertson, K.; Foster, R.; Swift, J.; Li, J.; et al. Mechanically activated Piezo1 channels of cardiac fibroblasts stimulate p38 mitogen-activated protein kinase activity and interleukin-6 secretion. J. Biol Chem 2019, 294, 17395-17408. [CrossRef] [PubMed]

45. Turner, N.A.; Porter, K.E.; Smith, W.H.T.; White, H.L.; Ball, S.G.; Balmforth, A.J. Chronic $\beta 2$-adrenergic receptor stimulation increases proliferation of human cardiac fibroblasts via an autocrine mechanism. Cardiovasc. Res. 2003, 57, 784-792. [CrossRef]

46. Van Nieuwenhoven, F.A.; Hemmings, K.E.; Porter, K.E.; Turner, N.A. Combined effects of interleukin- $1 \alpha$ and transforming growth factor- $\beta 1$ on modulation of human cardiac fibroblast function. Matrix Biol. 2013, 32, 399-406. [CrossRef] [PubMed]

47. Blaauw, E.; Lorenzen-Schmidt, I.; Babiker, F.A.; Munts, C.; Prinzen, F.W.; Snoeckx, L.H.; van Bilsen, M.; van der Vusse, G.J.; van Nieuwenhoven, F.A. Stretch-induced upregulation of connective tissue growth factor in rabbit cardiomyocytes. J. CardiovasC Transl Res. 2013, 6, 861-869. [CrossRef]

48. McMurray, J.J.; Packer, M.; Desai, A.S.; Gong, J.; Lefkowitz, M.P.; Rizkala, A.R.; Rouleau, J.; Shi, V.C.; Solomon, S.D.; Swedberg, K.; et al. Dual angiotensin receptor and neprilysin inhibition as an alternative to angiotensin-converting enzyme inhibition in patients with chronic systolic heart failure: Rationale for and design of the Prospective comparison of ARNI with ACEI to Determine Impact on Global Mortality and morbidity in Heart Failure trial (PARADIGM-HF). Eur J. Heart Fail. 2013, 15, 1062-1073. [CrossRef] [PubMed]

49. Calderone, A.; Bel-Hadj, S.; Drapeau, J.; El-Helou, V.; Gosselin, H.; Clement, R.; Villeneuve, L. Scar myofibroblasts of the infarcted rat heart express natriuretic peptides. J. Cell Physiol 2006, 207, 165-173. [CrossRef] [PubMed]

50. Kuhn, M.; Volker, K.; Schwarz, K.; Carbajo-Lozoya, J.; Flogel, U.; Jacoby, C.; Stypmann, J.; van Eickels, M.; Gambaryan, S.; Hartmann, M.; et al. The natriuretic peptide/guanylyl cyclase-a system functions as a stress-responsive regulator of angiogenesis in mice. J. Clin. Invest. 2009, 119, 2019-2030. [CrossRef] [PubMed]

51. Herum, K.M.; Lunde, I.G.; McCulloch, A.D.; Christensen, G. The Soft- and Hard-Heartedness of Cardiac Fibroblasts: Mechanotransduction Signaling Pathways in Fibrosis of the Heart. J. Clin. Med. 2017, 6, 53. [CrossRef] [PubMed]

52. Berry, M.F.; Engler, A.J.; Woo, Y.J.; Pirolli, T.J.; Bish, L.T.; Jayasankar, V.; Morine, K.J.; Gardner, T.J.; Discher, D.E.; Sweeney, H.L. Mesenchymal stem cell injection after myocardial infarction improves myocardial compliance. Am. J. Physiol Heart Circ. Physiol 2006, 290, H2196-H2203. [CrossRef] [PubMed]

53. Engler, A.J.; Carag-Krieger, C.; Johnson, C.P.; Raab, M.; Tang, H.Y.; Speicher, D.W.; Sanger, J.W.; Sanger, J.M.; Discher, D.E. Embryonic cardiomyocytes beat best on a matrix with heart-like elasticity: Scar-like rigidity inhibits beating. J. Cell Sci 2008, 121, 3794-3802. [CrossRef] [PubMed]

54. Chen, X.; Wanggou, S.; Bodalia, A.; Zhu, M.; Dong, W.; Fan, J.J.; Yin, W.C.; Min, H.K.; Hu, M.; Draghici, D.; et al. A Feedforward Mechanism Mediated by Mechanosensitive Ion Channel PIEZO1 and Tissue Mechanics Promotes Glioma Aggression. Neuron 2018, 100, 799-815 e797. [CrossRef]

55. Emig, R.; Knodt, W.; Krussig, M.J.; Zgierski-Johnston, C.M.; Gorka, O.; Gross, O.; Kohl, P.; Ravens, U.; Peyronnet, R. Piezo1 Channels Contribute to the Regulation of Human Atrial Fibroblast Mechanical Properties and Matrix Stiffness Sensing. Cells 2021, 10, 663. [CrossRef] [PubMed] 